\title{
TINGKAT KEPUASAN PENGGUNA DAN ANALISIS KEBUTUHAN PENGEMBANGAN LABORATORIUM JURUSAN
}

\author{
Sungkono, Estu Miyarso, Ariyawan Agung Nugroho \\ Fakultas Ilmu Pendidikan, Universitas Negeri Yogyakarta \\ sungkono@uny.ac.id; estu@uny.ac.id; ariyawan@uny.ac.id
}

\begin{abstract}
Abstrak
Tujuan penelitian ini untuk mengetahui tingkat kepuasan pengguna laboratorium Jurusan KTP FIP UNY saat ini dan untuk mengetahui gambaran kebutuhan apa saja untuk pengembangan laboratorium Jurusan KTP FIP UNY. Penelitian ini menggunakan pendekatan kuantitatif dengan jenis metode survey. Subjek penelitian ini adalah seluruh pengguna Laboratorium Jurusan KTP FIP UNY baik pengguna internal maupun eksternal. Adapun pengambilan sampel menggunakan teknik stratified random sampling . Adapun sampel penelitian ini berjumlah 175 mahasiswa. Instrumen pengumpulan data yang digunakan dalam penelitian ini yaitu angket tertutup dan terbuka. Teknik analisis data yang digunakan dalam penelitian ini yaitu deskriptif kuantitatif. Hasil penelitian menunjukkan bahwa tingkat kepuasan mahasiswa sebagai pengguna internal Lab Jurusan KTP FIP UNY termasuk pada kategori baik (rerata skor 3,52). Hal ini dapat diartikan pula bahwa tingkat kepuasan mahasiswa pengguna terhadap Lab Jurusan KTP FIP UNY pada tahun 2015 adalah tinggi. Indikator tingginya tingkat kepuasan pengguna lab jurusan ini ditunjukkan dari aspek tangible yang memperoleh rerata skor penilaian 3,48, aspek responsiveness dengan rerata skor penilaian 3,60, aspek assurance dengan rerata skor 3,53, dan aspek empathy dengan rerata skor 3,47. Hanya aspek reliability saja yang mendapat skor 3,42 atau masuk pada kriteria cukup. Hasil analisis kebutuhan menunjukkan bahwa secara keseluruhan sudah baik atau sudah memadai. Hal ini terbukti $61 \%$ dari 175 orang responden mahasiswa pengguna menilai bahwa ketersediaan sarana prasarana, SDM lab, dan program layanan sebagai komponen kebutuhan untuk pengembangan Lab Jurusan KTP FIP UNY sudah memadai.
\end{abstract}

Kata kunci: Analisis kebutuhan, pengembangan laboratorium.

\section{THE LEVEL OF USER SATISFACTION AND DEVELOPMENT NEEDS ANALYSIS OF DEPARTMENT LABORATOR}

\begin{abstract}
The purpose of this study was to determine the level of satisfaction of the current laboratory users of the KTP FIP UNY Department and to find an overview of the needs for the development of the KTP FIP UNY Department Laboratory. This research used a quantitative approach with a survey method. The subjects of this research were all users of the Department of KTP FIP UNY Laboratory, either internal or external users. We used stratified random sampling. The sample of this research was 175 students. We used closed and open questionnaires for data collection instruments and descriptive quantitative as data analysis techniques in this study. The results showed that the level of student satisfaction as an internal user of the KTP FIP UNY Department Lab was in a good category (mean score 3.52). This can also imply that the level of satisfaction of the KTP FIP UNY Department Lab users in 2015 was high. The indicator of the high level of user satisfaction in this department's lab is shown from the tangible aspect with a mean score of 3.48 , the responsiveness aspect with an average score of 3.60, the assurance aspect with a mean score of 3.53, and the empathy aspect with a mean score of 3.47. Only the reliability aspect got a score of 3.42 and included sufficient criteria. The needs analysis result showed that overall was good or adequate. This result was proven by $61 \%$ of the 175 student respondents assessed the availability of infrastructure, laboratory human resources, and service programs as a component for the development of the KTP FIP UNY Department Lab and was indicated as adequate.
\end{abstract}

Keywords: Needs Analysis, Laborator Development

\section{PENDAHULUAN}

Laboratorium pendidikan atau sering disingkat lab merupakan sarana penunjang kegiatan akademik pada suatu lembaga pendidikan. Dalam kondisi tertentu, lab dapat berfungsi sebagai salah satu komponen penting pendidikan sebagaimana komponen lainnya seperti pendidik, peserta didik, tujuan, kurikulum, dan evaluasi. Hal ini bisa terjadi bila lab dikelola dan dikembangkan secara optimal sehingga selain menjadi atau menyediakan sarana dan prasarana akademik, lab juga dapat menjadi lingkungan belajar 
bahkan menjadi pusat sumber belajar yang sangat dibutuhkan oleh para penggunanya.

Dalam konteks perguruan tinggi, lab memiliki peran yang sangat strategis dalam upaya pengembangan keilmuan maupun kelembagaan jurusan atau program studi (prodi). Hal ini sebagaimana disebutkan dalam Ketentuan Umum Permen PAN dan RB No.3 Tahun 2010 tentang Jabatan Fungsional Pranata Laboratorium Pendidikan dan Angka Kreditnya Pasal 1 bahwa Laboratorium Pendidikan yang selanjutnya disebut laboratorium adalah unit penunjang akademik pada lembaga pendidikan, berupa ruangan tertutup atau terbuka, bersifat permanen atau bergerak, dikelola secara sistematis untuk kegiatan pengujian, kalibrasi, danatau produksi dalam skala terbatas, dengan menggunakan peralatan dan bahan berdasarkan metode keilmuan tertentu, dalam rangka pelaksanaan pendidikan, penelitian, dan pengabdian kepada masyarakat.

Berdasarkan pengertian tersebut, nampak jelas bahwa istilah lab tidak lagi dibatasi pada bangunan fisik dalam bentuk ruangan atau bangunan tertutup tapi juga meliputi tempat atau area terbuka dan bersifat dinamis. Dari segi fungsinya, selain sebagai penunjang aktivitas pendidikan atau pengajaran, lab juga berfungsi sebagai tempat penyelenggaraan aktivitas penelitian dan pengabdian pada masyarakat. Ketiga fungsi ini jelas merupakan ciri dari aktivitas dan peran yang dilakukan oleh lembaga perguruan tinggi dibanding lembaga-lembaga pendidikan lainnya.

Persoalan yang terjadi adalah masih banyak jurusan atau prodi di beberapa perguruan tinggi yang memandang bahwa lab hanya sebagai penunjang kegiatan pendidikan terutama untuk memenuhi kelas praktek. Tentu menjadi hal yang tidak mengherankan bila ada beberapa jurusan atau prodi di perguruan tinggi terutama swasta tertentu yang sama sekali tidak memiliki fasilitas lab dengan alasan minimnya mata kuliah praktek yang diselenggarakannya. Belum termasuk prodi atau jurusan yang memang secara finansial tidak cukup untuk mengadakan atau mengembangkan fasilitas lab ini. Demikian juga dalam hal ketersediaan peralatan untuk mendukung perkuliahan praktek tersebut. Rasio jumlah peralatan yang dimiliki dengan jumlah mahasiswa sampai saat ini belum cukup.

Persoalan yang lebih penting selain masalah fisik baik berupa ketersediaan tempat, bahan dan peralatan yaitu sistem tata kelola dan sistem layanan. Bahkan masalah fisik ini justru sering menjadi akibat atau dampak dari pelaksanaan sistem tata kelola dan sistem layanan dari lab itu sendiri. Berdasarkan pengalaman peneliti di lapangan, sejauh ini belum pernah dilakukan kajian analisis kebutuhan dari pihak pengguna apalagi mengukur tingkat kepuasan mereka. Analisis masalah dan kebutuhan pengembangan lab yang sering dilakukan biasanya hanya berdasar pada rasio dan asumsi dari dosen selaku pengurus jurusan. Padahal sekali lagi, lab secara institusi merupakan unit layanan akademik yang dalam pengelolaannya tidak terlepas dari fungsi kontrol penggunanya.

Mengukur tingkat kepuasan pengguna merupakan suatu upaya menjalankan fungsi kontrol terutama dalam hal kualitas sistem tata kelola dan sistem layanan lembaga tertentu termasuk lab jurusan. Hal ini sebagaimana diungkapkan oleh Almasdi Syahza (2011) bahwa bagi perguruan tinngi yang bermutu, laboratorium menjadi bagian yang dikedepankan. Manajemen laboratorium perlu direncanakan seiring dengan perencanaan akademik. Peranan laboratorium sangat besar dalam menentukan mutu pendidikan karena laboratoriumlah yang menghasilkan karyakarya ilmiah yang membanggakan, yang tak dapat dihasilkan oleh institusi lainnya.

Sementara itu, Sulistyanto (dalam Hari Santoso, 2001) mengemukakan secara lebih rinci bahwa tingkat kepuasan pengguna atau pelanggan terhadap layanan tertentu termasuk sistem layanan di lab dipengaruhi oleh beberapa faktor, yaitu : (1) Keberadaan sarana danprasarana layanan (availability of service), yaitu suatu kondisi ketersediaan perlengkapan kerja dan fasilitas-fasilitas lain yang berfungsi sebagai alat bantu pelaksanaan layanan kepada masyarakat pengguna, (2) Ketanggapan staf 
layanan (responsiveness of the staff), yaitu kemauan staf layanan untuk tanggap dan bersedia membantu kepentingan pengguna yang memerlukan layanan,(3) Keahlian staf layanan (professionalism of the staff), yaitu kemampuan dan keterampilan staflayanan dalam melaksanakan tugas atau pekerjaan di bidangnya, (4) Ketuntasan layanan yang diberikan (completeness of service), yaitu kemauan aparat layanan untuk menjamin bahwa layanan yang diharapkan pengguna dapat diselesaikan sesuai ketentuan yang berlaku.

Menurut Kotler yang dikutip Tjiptono (1996:146) bahwa kepuasan pelanggan adalah tingkat perasaan seseorang setelah membandingkan kinerja (atau hasil) yang dirasakan dengan harapannya. Jadi, tingkat kepuasan adalah fungsi dari perbedaan antara kinerja yang dirasakan dengan harapan. Kualitas termasuk semua elemen yang diperlukan untuk memuaskan tujuan pelanggan, baik internal maupun ekternal, juga termasuk tiap-tiap item dalam produk kualitas, kualitas layanan, performance, availibility, durability, aesthetic, reability, maintain ability, logistic, support ability, costomer service, training, delivery, billing shipping, repairing, marketing warranty, dan life cycle cost.

Melalui komunikasi, baik antar pelanggan maupun dengan supplier akan menjadikan harapan bagi pelanggan terhadap kualitas produk yang akan dibelinya. Pemahaman terhadap harapan-harapan pelanggan oleh supplier merupakan input untuk melakukan perbaikan dan peningkatan kualitas produk, baik barang maupun jasa. Pelanggan akan membandingkan dengan produk jasalainnya. Bilamana harapanharapannya terpenuhi, maka akan menjadikannya pelanggan loyal, puas terhadap produk barang atau jasa yang dibelinya. Sebaliknya, bilamana tidak puas, supplierakan ditinggalkan oleh pelanggan.

Ada beberapa faktor yang berpengaruh terhadap kepuasan pelanggan, Tjiptono (1996:159) mengatakan bahwa ketidakpuasan pelanggan disebabkan oleh faktor internal dan faktor eksternal. Faktor internal yang relatif dapat dikendalikan perusahaan, misalnya karyawan yang kasar, jam karet, kesalahan pencatatan transaksi. Sebaliknya, faktor eksternal yang di luar kendali perusahaan, seperti cuaca, gangguan pada infrastruktur umum, aktivitas kriminal, dan masalah pribadi pelanggan.

Sehubungan dengan hal tersebut di atas, kepuasan pelanggan juga sangat dipengaruhi oleh tingkat pelayanan. Menurut Moenir (1998:197), agar layanan dapat memuaskan orang atau sekelompok orang yang dilayani, ada empat persyaratan pokok, yaitu (1) tingkah laku yang sopan,(2) cara menyampaikan sesuatu yang berkaitan dengan apa yang seharusnya diterima oleh orang yang bersangkutan, (3) waktu penyampaian yang tepat, dan (4) keramahtamahan.

Faktor pendukung yang tidak kalah pentingnya dengan kepuasan diantaranya faktor kesadaran para pejabat atau petugas yang berkecimpung dalam pelayanan umum, faktor aturan yang menjadi landasan kerja pelayanan, faktor organisasi yang merupakan alat serta sistemyang memungkinkan berjalannya mekanisme kegiatan pelayanan, faktor pendapatan yang dapat memenuhi kebutuhan hidup minimum, faktor keterampilan petugas, dan faktor sarana dalam pelaksanaan tugas pelayanan.

Sulistyanto (dalam Hari Santoso, 2001) mengemukakan secara lebih rinci bahwa tingkat kepuasan pengguna atau pelanggan terhadap layanan tertentu termasuk sistem layanan di lab dipengaruhi oleh beberapa faktor, yaitu : (1) Keberadaan sarana dan prasarana layanan (availability of service), yaitu suatu kondisi ketersediaan perlengkapan kerja dan fasilitas-fasilitas lain yang berfungsi sebagai alat bantu pelaksanaan layanan kepada masyarakat pengguna, (2) Ketanggapan staf layanan (responsiveness of the staff), yaitu kemauan staf layanan untuk tanggap dan bersedia membantu kepentingan pengguna yang memerlukan layanan,(3) Keahlian staf layanan (professionalism of the staff), yaitu kemampuan dan keterampilan staf layanan dalam melaksanakan tugas atau pekerjaan di 
bidangnya, (4) Ketuntasan layanan yang diberikan (completeness of service), yaitu kemauan aparat layanan untuk menjamin bahwa layanan yang diharapkan pengguna dapat diselesaikan sesuai ketentuan yang berlaku.

\section{Analisis Kebutuhan Pengembangan}

Kebutuhan (need) menunjukkan adanya sesuatu yang kurang dan harus ada upaya pemenuhannya. Kebutuhan dalam pembelajaran berarti dapat diartikan dalam istilah sebagai suatu kebutuhan yang sangat krusial dipenuhi dalam suatu sistem belajar (pembelajaran).

Atwi Suparman (2001:63) menyatakan bahwa kebutuhan adalah kesenjangan antara keadaan sekarang dengan yang seharusnya. Sementara Morrison (2001:27) membedakan antara kebutuhan dengan keinginan. Kebutuhan (need) diartikan sebagai kesenjangan antara apa yang diharapkan dengan kondisi yang sebenarnya, sedangkan keinginan adalah harapan ke depan atau citacita yang terkait dengan pemecahan suatu masalah. Sedangkan analisis kebutuhan menurut Morrison (2001: 27) adalah alat untuk mengidentifikasi masalah guna menentukan tindakan yang tepat.

\section{Laboratorium sebagai Pusat Sumber Belajar (PSB)}

Kata laboratorium berasal dari kata laboratory, yang memiliki beberapa pengertian yaitu: a) Tempat yang dilengkapi peralatan untuk melangsungkan eksperimen didalam sains atau melakukan pengujian dan analisis. b) Bangunan atau ruang yang dilengkapi peralatan untuk melangsungkan penelitian ilmiah ataupun praktek pembelajaran bidang sains. c) Tempat memproduksi bahan kimia atau obat. d) Tempat kerja untuk melangsungkan penelitian ilmiah. e) Ruang kerja seorang ilmuwan dan tempat menjalankan eksperimen bidang studi sains (kimia, fisika, biologi). Menurut Ketentuan Umum Permen PAN dan RB No.3 Tahun 2010 tentang Jabatan Fungsional Pranata Laboratorium Pendidikan dan Angka
Kreditnya Pasal 1 bahwa Laboratorium Pendidikan yang selanjutnya disebut laboratorium adalah unit penunjang akademik pada lembaga pendidikan, berupa ruangan tertutup atau terbuka, bersifat permanen atau bergerak, dikelola secara sistematis untuk kegiatan pengujian, kalibrasi, danatau produksi dalam skala terbatas, dengan menggunakan peralatan dan bahan berdasarkan metode keilmuan tertentu, dalam rangka pelaksanaan pendidikan, penelitian, dan pengabdian kepada masyarakat. Sedangkan istilah Pusat Sumber Belajar (PSB) merupakan pemusatan berbagai sumber belajar yang meliputi orang, bahan, peralatan, fasilitas lingkungan, tujuan dan proses. Secara umum PSB berisi komponenkomponen perpustakaan, pelayanan audiovisual, peralatan dan produksi, tempat berlatih mengembangkan kegiatan program instruksional dan tempat mengembangkan alat-alat bantu dalam pengembangan sistem instruksional. PSB juga merupakan tempat bagi tenaga kependidikan untuk mengembangkan bahan-bahan pengajaran dengan bantuan multimedia pendidikan terpadu yang terdiri atas unsur-unsur perpustakaan, workshop, audio-visual dan laboratorium (Zainuddin : 1984 dalam Samosir Bravo, 2012). Laboratorium sebagai pusat sumber belajar yang dimaksud adalah lab yang memiliki fungsi sebagaimana pusat sumber belajar. Adapun fungsinya meliputi fungsi produksi, pengembangan, pengelolaan, pelayanan maupun administratif. Hal ini sebagaimana diungkapkan oleh Mudoffir (1986: 13-15) yaitu Pusat Sumber Belajar mempunyai fungsi pengembangan sistem instruksional, fungsi pelayanan media, fungsi produksi, dan administratif. Fungsi pengembangan sistem instruksional sangat membantu bagi para tenaga edukatif dalam merancang dan memilih desain pembelajaran yang akan digunakan dalam proses pembelajaran. Fungsi pelayanan media sangat berkaitan dengan penyediaan media atau alat bantu yang akan digunakan dalam proses pembelajaran baik oleh tenaga edukatif maupun oleh mahasiswa. Fungsi Pelayanan berhubungan dengan pelayanan baik 
pelayanan pembuatan program media, peminjaman, konsultasi, dan pemeliharaan. Fungsi administratif berhubungan dengan cara bagaimana tujuan dan prioritas program dapat tercapai. Keempat fungsi ini merupakan fungsi yang ideal dimiliki oleh suatu laboratorium sebagai pusat sumber belajar.

\section{METODE PENELITIAN}

Penelitian ini menggunakan pendekatan kuantitatif dengan jenis metode survey. Subjek penelitian ini adalah seluruh pengguna Lab Jurusan KTP FIP UNY. Adapun pengambilan sampel menggunakan teknik stratified random sampling. Adapun sampel penelitian ini berjumlah 175 mahasiswa.

Instrumen pengumpulan data yang digunakan dalam penelitian ini yaitu angket tertutup dan terbuka. Angket ini akan mengungkap tingkat kepuasan pengguna lab jurusan yang meliputi dari aspek tangible, aspek responsiveness, aspek assurance, aspek empathy. Dan mengungkap analisis kebutuhan pengembangan Lab Jurusan KTP.

Teknik analisis data yang digunakan dalam penelitian ini yaitu deskriptif kuantitatif. Data yang berupa pernyataan sangat baik, baik, cukup, kurang, dan sangat kurang yang diubah menjadi data kuantitatif dengan skala 5, yaitu dengan penskoran dari 1 sampai 5 .

Dalam angket ini diberikan 5 pilihan untuk memberikan tanggapan tentang analisis kebutuhan pengembangan laboratorium sebagai pusat sumber belajar di jurusan KTP FIP UNY yaitu, sangat baik (5), baik (4), cukup (3), kurang (2) dan (1) sangat kurang. sedangkan data dari pemaparan atau penjelaskan yang dinyatakan dengan kata-kata berdasarkan jawaban responden melalui angket terbuka, teknik analisis data yang digunakan peneliti yaitu analisis data deskriptif kualititatif yang kemudian dikonversi menjadi nilai dengan skala 5 .

\section{HASIL DAN PEMBAHASAN}

\section{A. Hasil Penelitian}

1. Tingkat Kepuasan Pengguna Lab Jurusan KTP FIP UNY
Aspek tingkat kepuasan pengguna lab Jurusan KTP FIP UNY meliputi; aspek tangible (pelayanan bersifat nyata), reliability (dapat dipercaya), responsiveness (bersikap tanggap), assurance (dapat menjamin), dan empathy (menunjukkan kesungguhan). Hasil penelitian tentang kelima hal tersebut dapat disajikan sebagai berikut: 1) Aspek Tangible (Pelayanan Bersifat Nyata), data hasil angket menunjukkan bahwa dari 175 orang responden yang menjawab 5 butir pertanyaan terkait dengan aspek tangible ini mayoritas berada pada kategori baik. Secara keseluruhan penilaian dari mahasiswa sebagai responden pada aspek tangible atau pelayanan nyata di lab Jurusan KTP FIP UNY ini ada pada kriteria baik dengan skor rerata 3,57. Untuk jawaban angket pada butir nomor 1 tentang kemudahan menjangkau ruang lab mendapat skor 3,89 atau masuk pada kriteria baik. Jawaban butir angket nomor 2 tentang sistem layanan yang diterapkan di lab mendapat skor 3,5 atau masuk kriteria baik. Adapun jawaban butir angket nomor 3 tentang bahan dan peralatan utama yang dimiliki lab hanya mendapat skor 3,40 atau masuk pada kriteria cukup baik. Butir nomor 4 tentang peralatan pendukung seperti listrik, pendingin ruang, toilet, dan sebagainya mendapat skor 3,8 atau berkriteria baik. Dan butir 5 tentang sistem pelayanan pengaduan mendapat skor 3,3 atau berkriteria cukup baik. 2.) Reliability (Dapat Dipercaya), hasil penelitian menunjukan bahwa dari 175 orang responden yang menjawab 4 butir pertanyaan terkait dengan aspek tingkat kepercayaan atau reliability ini mayoritasnyajustruberada pada kategori Cukup Baik dengan rerata skor 3,42. Secara keseluruhan penilaian dari mahasiswa sebagai responden pada aspek reliability atau tingkat kepercayaan terhadap lab Jurusan KTP FIP UNY ini ada pada kriteria baik dan cukup baik. Untuk jawaban angket pada butir nomor 6 tentang kualitas produk/ jasa layanan yang diberikan lab mendapat skor 3,5 atau masuk pada kriteria baik. Jawaban butir angket nomor 7 tentang kejelasan informasi kepada pengguna di lab mendapat skor 3,4 atau masuk kriteria cukup baik. Adapun jawaban butir angket nomor 8 tentang tarif atau biaya di lab 
mendapat skor 3,41 atau masuk pada kriteria cukup baik. Butir nomor 9 tentang kesesuaian biaya dengan layanan yang diberikan pada pengguna mendapat skor 3,4 atau berkriteria cukup baik. 3) Responsiveness (Sikap Tanggap), Data hasil angket menunjukkan bahwa penilaian aspek Sikap Tangap atau Responsiveness dari tenaga laboran atau petugas lab jurusan mayoritasnya berada pada kategori Baik dengan rerata skor penilaian 3,6. Secara keseluruhan penilaian dari mahasiswa sebagai responden pada aspek reliability atau tingkat kepercayaan terhadap lab Jurusan KTP FIP UNY ini ada pada kriteria baik dan cukup baik. Untuk jawaban angket pada butir nomor 10 tentang kemampuan petugas/ laboran lab mendapat skor 3,8 atau masuk pada kriteria baik. Jawaban butir angket nomor 11 tentang sikap petugas/ laboran kepada pengguna di lab mendapat skor 3,77 atau masuk kriteria baik. Adapun jawaban butir angket nomor 12 tentang sikap petugas atau laboran dalam menerima keluhan-keluhan pengguna mendapat skor 3,5 atau masuk pada kriteria baik. Butir nomor 13 tentang sikap petugas atau laboran dalam menerima saran-saran dari pengguna mendapat skor 3,51 atau berkriteria baik. Adapun jawaban untuk butir nomor 14 tentang kecepatan petugas atau laboran dalam merespon keluhan atau saran dari pengguna tersebut mendapat skor 3,4 atau masuk pada kriteria cukup baik. 4) Assurance (Adanya Menjamin), Data penelitian menunjukkan bahwa penilaian untuk aspek Jaminan dari Pengelola atau Assurance lab jurusan KTP FIP UNY mayoritasnya berada pada kategori Baik. Secara keseluruhan penilaian dari mahasiswa sebagai responden pada aspek reliability atau tingkat kepercayaan terhadap lab Jurusan KTP FIP UNY ini ada pada kriteria baik dan cukup baik. Untuk jawaban angket pada butir nomor 15 tentang jaminan kualitas jasa layanan yang diberikan lab mendapat skor 3,51 atau masuk pada kriteria baik. Jawaban butir angket nomor 16 tentang jaminan kualitas produk layanan lab mendapat skor 3,5 atau masuk kriteria baik. Adapun jawaban butir angket nomor 17 tentang kualitas keamanan selama di ruang lab mendapat skor 3,7 atau masuk pada kriteria baik. Butir nomor 18 tentang jaminan ketepatan waktu atas layanan kepada pengguna mendapat skor 3,57 atau berkriteria baik, dan butir 19 tentang jaminan layanan atas kemungkinan kesalahan dari pihak lab mendapat skor 3,4 atau berkriteria cukup baik. 5). Aspek Empathy (Menunjukkan Kesungguhan), hasil menunjukkan bahwa penilaian dari mayoritas responden untuk aspek Sikap Kesungguhan atau Empathy tenaga laboran atau petugas lab jurusan KTP FIP UNY mendapat rerata skor 3,47 atau berada pada kategori Baik. Secara keseluruhan penilaian dari mahasiswa sebagai responden pada aspek empathy atau tingkat kesungguhan pengelola lab Jurusan KTP FIP UNY ini ada pada kriteria baik dan cukup baik. Untuk jawaban angket pada butir nomor 20 tentang tingkat akses atau kemudahan terhadap produk/ jasa layanan yang diberikan lab mendapat skor 3,54 atau masuk pada kriteria baik. Jawaban butir angket nomor 21 mengenai tingkat kemudahan dalam menyampaikan keluhan atau saran kepada pengelola lab mendapat skor 3,4 atau masuk kriteria cukup baik. Butir nomor 22 tentang perhatian secara personal pada pengguna mendapat skor 3,45 atau berkriteria baik Adapun jawaban butir angket nomor 23 tentang usahan pengelola lab untuk tidak menunda pekerjaan atau layanan kepada pengguna mendapat skor 3,5 atau masuk pada kriteria baik.

2. Analisis Kebutuhan Pengembangan Lab Jurusan KTP FIP UNY

Data analisis kebutuhan pengembangan lab Jurusan KTP FIP UNY yang dijaring dalam penelitian ini meliputi data dari komponen sarana dan prasarana, komponen SDM (Sumber Daya Manusia) pengelola lab termasuk tenaga laboran dan petugas lab, serta komponen program layanan lab. Hasil penelitian dapat disajikan sebagai berikut: 1). Komponen Sarana Prasarana yang meliputi kecukupan bahan praktek yang ada di lab, 79\% responden menilai sudah memadai, kecukupan peralatan praktek lab, $86 \%$ responden menyatakan sudah memadai, ketersediaan peralatan emergency seperti kotak P3K, tabung pemadam kebakaran, dan 
sebagainya dirasa masih kurang oleh sebagian besar responden; ketersediaan peralatan keamanan seperti CCTV. Hal ini berarti bahwa $66 \%$ responden menilai perlu adanya peralatan tersebut untuk menambah keamanan di lab; ketersediaan ruang praktek, $93 \%$ responden menjawab dirasa sudah memadai oleh mayoritas responden; ketersediaan ruang tunggu dijawab sudah ada (79\%); ketersediaan buku pedoman atau panduan praktek dan petunjuk/alur layanan di lab belum ada atau belum jelas ketersediannya; ketersediaan buku catatan layanan di lab sudah tersedia (62\%); ketersediaan kotak saran di lab belum ada atau belum jelas keberadannya (45). 2) Sumber Daya Manusia (Tenaga Laboran/Petugas), Hasil penelitian menunjukkan ketersediaan jumlah SDM pengelola lab dirasa sudah cukup memadai oleh mayoritas responden.

\section{B. Pembahasan}

Berdasarkan hasil penelitian yang telah dipaparkan terdahulu menunjukkan bahwa tingkat kepuasan mahasiswa sebagai pengguna internal Lab Jurusan KTP FIP UNY pada kategori baik (skor 3,52). Hal ini dapat diartikan pula bahwa tingkat kepuasan mahasiswa pengguna terhadap Lab Jurusan KTP FIP UNY pada tahun 2015 adalah tinggi. Aspek Tangible lebih dimaknai sebagai bukti fisik. Aspek tangible ini mengukur sejauhmana lab jurusan mampu memberikan kepuasan atas keberadaan secara fisik baik letak gedung maupun kondisi ruangan lab Jurusan KTP FIP UNY. Letak gedung atau posisi geografis lab Jurusan KTP sehingga mudah dijangkau oleh pengguna mendapat skor 3,89 atau masuk pada kriteria baik. Ini adalah perolehan skor tertinggi pada aspek tangible ini. Artinya dari sisi letak dan posisi maka gedung atau ruangan lab Jurusan KTP FIP ini sudah cukup ideal menurut para penggunanya terutama mahasiswa.

Sistem layanan yang diterapkan lab jurusan selama ini yang diwakili dengan butir angket nomor 2. Berdasarkan gambar 4, sistem layanan yang diterapkan di lab mendapat skor 3,5 atau masuk kriteria baik.
Komponen ketiga dari aspek tangible dalam penelitian ini yaitu terkait dengan bahan dan peralatan utama yang dimiliki lab. Komponen ini hanya mendapat skor 3,40 atau masuk pada kriteria cukup. Artinya, ketersediaan alat dan bahan di lab jurusan perlu ditambah atau diperbaharui karena belum begitu memuaskan penggunanya.

Komponen aspek tangible yang keempat yaitu ketersediaan peralatan pendukung seperti listrik, pendingin ruang, toilet, dan sebagainya mendapat skor 3,8 atau berkriteria baik. Artinya ketersediaan sarana dan prasaran pendukung di lab terkait dengan hal-hal tersebut sudah tinggi dan memuaskan penggunanya.

Komponen kelima sebagai komponen terakhir dalam penelitian ini yaitu ada tidaknya sistem pelayanan pengaduan. Komponen ini hanya mendapat skor 3,3 atau berkriteria cukup. Meskipun masuk pada kriteria cukup, komponen inilahcyang paling rendah dalam perolehan skornya. Hal ini mengindikasikan bahwa perlunya pembenahan dalam hal layanan pengaduan seperti penyediaan kotak saran bagi pengguna, adanya papan informasi yang bisa diakses oleh pihak pengelola maupun pengguna, dan sebagainya.Faktanya hal yang disebutkan terakhir ini memang belum ada di lab jurusan.

Adapun untuk aspek kedua dari variabel tingkat kepuasan pengguna lab jurusan yaitu reliability atau tingkat kepercayaan. Aspek ini mendapat rerata skor 3,42 atau masuk pada kategori cukup. Aspek ini satu-satunya yang mendapat skor penilaian paling rendah dari mahasiswa pengguna dibanding empat aspek lainnya. Hal ini menunjukkan bahwa lab jurusn belum bisa memberikan tingkat kepercayaan yang tinggi kepada para penggunanya. Sementara itu, untuk komponen lainnya yaitu kejelasan informasi kepada pengguna di lab hanya mendapat skor 3,4 atau masuk kriteria cukup baik. Demikian juga tentang tarif atau biaya di lab mendapat skor 3,41 atau masuk pada kriteria cukup baik. Komponen terakhir tentang kesesuaian biaya dengan layanan yang diberikan pada pengguna juga hanya mendapat skor 3,4 atau berkriteria 
cukup baik. Artinya ketiga komponen terakhir ini memang perlu segera dibenahi agar tingkat kepercayaan pengguna pada waktu-waktu berikutnya bisa lebih tinggi. Aspek yang ketiga dari variabel tingkat kepuasan pengguna yaitu responsiveness atau sikap tanggap yang diberikan oleh pihak petugas atau laboran kepada pengguna. Secara keseluruhan, aspek ini mendapat rerata skor penilaian 3,6 atau masuk pada kategori baik.

Komponen keempat tentang sikap petugas atau laboran dalam menerima saransaran dari pengguna mendapat skor 3,51 atau berkriteria baik. Adapun komponen kelima tentang kecepatan petugas atau laboran dalam merespon keluhan atau saran dari pengguna tersebut mendapat skor 3,4 atau hanya masuk pada kriteria cukup baik. Berdasarkan data ini, dapat diartikan bahwatingkat kepuasan pengguna pada aspek responsiveness atau sikap tanggap dari petugas lab sudah tinggi. Namun demikian dalam hal kecepatan merespon keluhan dan masukan dari pengguna lab perlu menjadi perhatian dan pembenahan agar dapat lebih baik lagi.

Aspek yang keempat dari variabel tingkat kepuasan pengguna yaitu assuranceatau adanya jaminan yang diberikan oleh pihak pengelola lab jurusan terhadap pengguna. Secara keseluruhan, aspek ini mendapat rerata skor penilaian 3,53 atau masuk pada kategori baik.

Berdasarkan gambar 10pada bab IV, aspek ini dijabarkan menjadi 5 komponen yang terwakili dalam 5 butir pertanyaan pada angket nomor $15-19$. Komponen pertama pada aspek ini tentang jaminan kualitas jasa layanan yang diberikan lab mendapat skor 3,51 atau masuk pada kriteria baik. Komponen kedua tentang jaminan kualitas produk layanan lab mendapat skor 3,5 atau masuk kriteria baik. Komponen ketiga tentang kualitas keamanan selama di ruang lab mendapat skor 3,7 atau masuk pada kriteria baik. Komponen keempat tentang jaminan ketepatan waktu atas layanan kepada pengguna mendapat skor 3,57 atau berkriteria baik. Namum demikian untuk komponen kelima tentang jaminan layanan atas kemungkinan kesalahan dari pihak lab hanya mendapat skor 3,4 atau berkriteria cukup baik.

Berdasarkan hasil penelitian ini dapat dikatakan bahwa aspek assurance atau jaminan yang diberikan oleh pengelola kepada pengguna sudah tinggi. Namun demikian, untuk jaminan atas kemugkinan kesalahan dari pihak lab dalam memberikan layanan baik dari sisi produk maupun jasanya nampaknya perlu ditingkatkan lagi.

Aspek yang kelima dari variabel tingkat kepuasan pengguna untuk penelitian ini yaitu empatyatau kesungguhan petugas dan laboran dalam memberikan layanan kepada pengguna. Secara keseluruhan, aspek ini mendapat rerata skor penilaian 3,47 atau masuk pada kategori baik.

Semua indikator menunjukkan penilaian yang positif terhadap komponen program layanan ini meskipun dengan persentase yang tidak lebih dari $80 \%$.

\section{PENUTUP}

Berdasarkan hasil penelitian dan pembahasan dapat disimpulkan bahwa: 1) Tingkat kepuasan mahasiswa sebagai pengguna internal Lab Jurusan KTP FIP UNY termasuk pada kategori baik (rerata skor 3,52). Hal ini dapat diartikan pula bahwa tingkat kepuasan mahasiswa pengguna terhadap Lab Jurusan KTP FIP UNY pada tahun 2015 adalah tinggi. Indikator tingginya tingkat kepuasan pengguna lab jurusan ini ditunjukkan dari aspek tangible yang memperoleh rerata skor penilaian 3,48, aspek responsiveness dengan rerata skor penilaian 3,60, aspek assurance dengan rerata skor 3,53 , dan aspek empathy dengan rerata skor 3,47. Hanya aspek reliabilty saja yang mendapat skor 3,42 atau masuk pada kriteria cukup. 2) Hasil analisis kebutuhan menunjukkan bahwa secara keseluruhan sudah baik atau sudah memadai. Hal ini terbukti $61 \%$ dari 175 orang responden mahasiswa pengguna menilai bahwa ketersediaan sarana prasarana, SDM lab, dan program layanan sebagai komponen kebutuhan untuk pengembangan Lab Jurusan KTP FIP UNY sudah memadai. Beberapa hal yang perlu mendapat perhatian dan pembenahan dari 
komponen sarana prasarana yaitu; belum atau kurangnya ketersediaan peralatan emergency seperti kotak P3K, tabung pemadam kebakaran, peralatan keamanan seperti kamera CCTV, buku pedoman praktik dan petunjuk alur informasi layanan lab. Hal yang perlu diperhatikan dan dibenahi pada komponen SDM yaitu perlunya sambutan hangat dari petugas lab saat pengguna masuk ruangan lab. Adapun pada komponen program layanan semua indikatornya mendapat penilaian yang positif dari mayoritas responden. Atas dasar ini dapat disarankan kepada jurusan KTP untuk lebih meningkatkan pelayanannya.

\section{DAFTAR PUSTAKA}

Abidin, Z Analisis Kebutuhan Pembelajaran, http://eprints.ums.ac.id/4610/,

Kementerian Pendayagunaan Aparatur Negara dan Reformasi Birokrasi. 2010. Peraturam Menteri PAN dan RB No.3 Tahun 2010 tetang Jabatan Fungsional Pranata laboratorium dan Angka Kreditnya. Jakarta: Kemen PANRB

Kemp, EJ. 1994. Proses Perancangan Pengajaran, terjemahan Asril Marjohan, Namdung, ITB.
Morrison, Ross, GR, Ross, SM,. Kemp, EJ. 2001. Designing Effective Instruction, Third Edition. USA: John Wiley and Sons.

Mudoffir. 1986. Prinsip-prinsip Pengelolaan Sumber Belajar. Bandung: Remadja Karya.

Santoso, H. 2011. Metode Pengukuran Tingkat

Kepuasan Pemakai Perpustakaan

Perguruan Tinggi. Makalah lepas.

Malang: UPT Perpustakan UNM

Samosir, B dalam "Struktur Organisasi Pusat

Sumber Belajar" diakses di http//struktur-organsasi-pusat-sumberbelajar.html pada tanggal 11 April 2014 Suparman. A 2004. Desain Instruksional, Jakarta: Pusat Penerbitan Universitas Terbuka.

Tim Borang Akreditasi Jurusan. 2014. Naskah Borang Akreditasi Jurusan KTP FIP UNY tahun 2014. Yogyakarta: KTP FIP UNY

Tim Evaluasi diri Akreditasi Jurusan. 2014.

Naskah Evaluasi Diri Akreditasi Jurusan KTP FIP UNY tahun 2014. Yogyakarta: KTP FIP UNY

Tjiptono. 1996. Total Manajemen Pelayanan Publik. Jakarta: Rineka Cipta 